\title{
An X-factor Requiring Haemophilus Species
}

\author{
By W. J. RYAN \\ Public Health Laboratory, Exeter \\ (Accepted for publication 8 January 1968) \\ SUMMARY \\ The isolation from a perianal abscess of a Haemophilus species requiring
} for growth the presence of X-factor but not V-factor is recorded. Two other similar strains were isolated from normal faeces. The properties of these isolates are given and compared with those of previously described species of the genus Haemophilus having the same growth requirements. The isolates form a homogeneous group resembling Haemophilus influenzae-murium.

\section{INTRODUCTION}

All members of the genus Haemophilus have in common the characteristic of requiring for growth certain accessory factors normally present in blood. Two of these essential growth substances have been identified, haematin or the $\mathrm{X}$-factor and nicotinamide adenine dinucleotide (diphosphopyridine nucleotide) or the V-factor. The genus has been subdivided according to growth-factor requirements. Thus Pittman (I957) listed 15 species of which five require both X-and V-factors, two require V-factor only, and five require $\mathrm{X}$-factor only. The remaining three species require factors as yet unidentified. The species listed as requiring $\mathrm{X}$-factor only are Haemophilus aphrophilus, $H$. influenzae-murium, $H$. ovis, $H$. ducreyi and $H$. haemoglobinophilus. Only two of these species have been found in human infections, $H$. aphrophilus and $H$.ducreyi. The present paper describes a member of this genus which requires X-factor only, isolated from a perianal abscess in a woman aged 45 years.

\section{METHODS}

Morphology. Morphology was routinely investigated in smears stained by Gram method. Motility was determined in hanging-drop preparations of young cultures in suitable liquid media. The wet indian-ink method (Duguid, 195I) was used for demonstrating capsules.

\section{Physiology}

Gas-phase conditions. The optimal gas-phase conditions for growth were determined by incubation of inoculated blood-agar plates in air, in a candle-jar for increased $\mathrm{CO}_{2}$ tension, and anaerobically in a McIntosh \& Fildes jar.

Temperature. The optimum temperature for growth was found by incubation of inoculated blood-agar plates at $37^{\circ}, 30^{\circ}$ and $25^{\circ}$.

Optimum $\mathrm{pH}$ value. Gradient plates, prepared according to the method of Watson \& Bennett (1957), were used to determine the optimum $\mathrm{pH}$ value for growth and the $\mathrm{pH}$ range. Peptone water agar containing the $\mathrm{X}$-factor was the basal medium used.

Nutritional requirements. All experiments on growth requirements were done under 
optimal gas-phase, temperature and $\mathrm{pH}$ conditions. Small inocula were used throughout. Bacterial suspensions were made, in quarter-strength Ringer solution, of sufficient concentration to give semi-confluent growth or less when a $3 \mathrm{~mm}$. loopful was inoculated on a segment of a plate. Serial subcultures were done when growth occurred. The following media were used: Koser citrate medium (Gillies, I960), I \% (w/v) Oxoid peptone water, peptone water medium solidified with $\mathrm{I} \%(\mathrm{w} / \mathrm{v})$ Davis powdered agar, peptone water agar enriched with $\mathrm{X}$-factor, with V-factor, and with $\mathrm{X}$-factor + V-factor together, Lemco nutrient broth, Lemco nutrient agar, Lemco nutrient broth and agar enriched with $10 \%(\mathrm{v} / \mathrm{v})$ horse serum, Lemco nutrient agar enriched with $10 \%(\mathrm{v} / \mathrm{v})$ horse blood, and chocolate agar prepared from Lemco nutrient agar containing $10 \%(\mathrm{v} / \mathrm{v})$ horse blood heated at $70^{\circ}$ for $10-15 \mathrm{~min}$.

$\mathrm{X}$ - and V-factors were prepared from haematin and from brewer's yeast, respectively, as described by Stokes (I960). The final concentration of haematin in the medium was $50 \mu \mathrm{g} . / \mathrm{ml}$.; yeast extract was added to a final concentration of $10 \%(\mathrm{v} / \mathrm{v})$.

Action on carbohydrates. Peptone water containing X-factor and I \% (w/v) of the appropriate carbohydrate was used with Andrade indicator. Cultures were incubated for 3 weeks at $37^{\circ}$ before results were recorded as negative. The method of Hugh \& Leifson (1953) was used to determine whether acid production from glucose was the result of a fermentative or oxidative process. Starch hydrolysis was tested by incorporating $0.02 \%(\mathrm{w} / \mathrm{v})$ soluble starch in peptone water agar containing X-factor. After 3 days of incubation at $37^{\circ}$ the starch plates were flooded with Gram iodine; clear zones were an indication of hydrolysis.

Oxidase. A few drops of a freshly prepared I \% (w/v) solution of tetramethyl-pphenylenediamine hydrochloride were poured over a $24 \mathrm{hr}$ culture on blood agar and rapid development of a purple colour noted.

Catalase. A small amount of growth from peptone water X-factor agar was suspended in a drop of ' 20 vol.' hydrogen peroxide on a glass slide and production of effervescence noted.

Urease. A heavy inoculum was placed on the centre of a slope of Christensen medium (Christensen, 1946) and incubated for $24 \mathrm{hr}$ at $37^{\circ}$.

Nitrate reduction. A strip of filter paper impregnated with potassium nitrate was laid across the surface of a blood agar plate and stab inoculations made into the medium adjacent to the strip (Cook, 1950). Browning of the medium around the inoculum indicated reduction of nitrate. Readings were taken after incubation for 24 and $48 \mathrm{hr}$. The conventional Griess-Ilosvay method was not used as satisfactory growth could not be obtained in nitrate-containing broth.

Egg-yolk reaction. Organisms were grown on Lemco nutrient agar containing $\mathrm{X}$-factor and 10 \% (v/v) egg-yolk saline. The egg-yolk saline was prepared by emulsifying the yolk of one egg in $250 \mathrm{ml}$. physiological saline and sterilizing by Seitz filtration. Readings were taken after incubation for $48 \mathrm{hr}$.

Indole. Organisms were grown for $48 \mathrm{hr}$ at $37^{\circ}$ in peptone water containing X-factor. Ehrlich reagent was used to test for indole production after extraction of cultures with ether.

Serum liquefaction. Liquefaction of coagulated serum was tested on Loeffler serum slopes. Readings were taken after 24 and $48 \mathrm{hr}$.

Gelatin liquefaction. Nutrient gelatin containing X-factor was used. Incubation was at $37^{\circ}$ and was, when necessary, prolonged for 2 weeks. 
Casein hydrolysis. Organisms were grown on Lemco nutrient agar containing Xfactor and $10 \%(\mathrm{v} / \mathrm{v})$ skim milk. A positive reaction was indicated by clear zones around colonies after 2-3 days of incubation.

Fibrinolysis. Fresh human plasma 10 \% (v/v) was added to melted Lemco nutrient agar containing X-factor and the fibrinogen precipitated by heat at $56^{\circ}$ (Christie \& Wilson, 194I). Plates were poured, dried and inoculated. Clear zones around colonies after 2-3 days of incubation indicated fibrinolysin production.

Litmus milk. X-factor was incorporated in ordinary litmus milk. Cultures were incubated, when necessary, for 3 weeks.

Amino acid breakdown and sodium malonate utilization. Decarboxylation of lysine, deamination of phenylalanine and utilization of sodium malonate were investigated by micro-methods (Shaw \& Clarke, 1955). Positive and negative controls were included with all tests.

Haemolysis. Lemco nutrient agar plates containing X-factor and $2 \%(\mathrm{v} / \mathrm{v})$ washed red blood cells were used. Horse, human, rabbit, sheep and chicken red cells were tested, by using layered plates. Results were read after incubation for 24 and $48 \mathrm{hr}$.

Haemagglutination. A drop of a heavy bacterial suspension in saline was added to a drop of $10 \%(\mathrm{v} / \mathrm{v})$ washed red blood cell suspension on a slide and rocked gently for 2-3 min. Human group $O$, rabbit and chicken red cells were used; the test was done at room temperature (about $18^{\circ}$ ) and at $4^{\circ}$.

Sodium chloride tolerance. Sodium chloride was incorporated in Lemco nutrient agar containing X-factor in the following concentrations (\% w/v): $5 \cdot 5,4 \cdot 5,3 \cdot 5,2 \cdot 5$, $\mathrm{I} \cdot 5,0.5$. Plates were inoculated with a drop of a light bacterial suspension, sufficient to give semi-confluent growth on control plates containing $0.5 \% \mathrm{NaCl}$. Readings were taken after 3-4 days of incubation.

Heat-resistance. Heavy bacterial suspensions in peptone water were placed in small screw-capped bottles and immersed in water baths at $56^{\circ}$ and $100^{\circ}$. At intervals a large loopful was removed and plated on blood agar.

Viability. Survival at $37^{\circ}$, at room temperature, and at $4^{\circ}$ was determined by storing fully grown blood agar cultures at these temperatures in the dark and subculturing at intervals to fresh blood agar plates.

Resistance to inhibitory agents. The effect of potassium tellurite, sodium azide and crystal violet was examined by incorporating these substances in blood agar in the following final concentrations (w/v): potassium tellurite $1 / 15,000$; sodium azide $\mathrm{I} / 2,500, \mathrm{I} / 5,000$; crystal violet $\mathrm{I} / \mathrm{I} 25,000, \mathrm{I} / 250,000, \mathrm{I} / 500,000$. A drop of bacterial suspension sufficient to give semi-confluent growth on control plates was used as inoculum. Results were read after 3-4 days.

Antibiotics and chemotherapeutic agents. Sensitivity tests were done on blood agar plates by using commercialy available discs. In addition, sensitivity to penicillin and to neomycin was investigated by the tube dilution method, using as basal medium Lemco nutrient broth containing X-factor. Results were recorded after 2 days.

\section{Antigenic structure}

Suspensions of organisms in formol saline (physiological saline containing $0.5 \%$ (v/v) formalin), made up to a concentration of about 3000 million organisms $/ \mathrm{ml}$. were used to immunize rabbits. Sera taken before beginning the injections contained no agglutinins against the immunizing organisms. The dosage schedule used was that 
described by Boyd ( 1947 ), I.0 $\mathrm{ml}$. doses being used with 3 intravenous injections on the first 3 days of the first week, followed by 2 intravenous and one intraperitoneal injection on the first 3 days of the 3 succeeding weeks. The animals were bled I week after completing the course, provided that a trial bleeding showed satisfactory results.

Agglutination tests were done in Dreyer tubes in a $52^{\circ}$ water bath using as antigens suspensions containing about 300 million organisms $/ \mathrm{ml}$. Both formolized suspensions. and suspensions heated at $100^{\circ}$ for $15 \mathrm{~min}$. were used as antigens.

\section{RESULTS}

A specimen of pus from a perineal abscess of 5 weeks duration in a woman aged 45 years was submitted for bacteriological examination. Aerobic blood agar plates showed a moderate growth of Escherichia coli and a profuse growth of a small Gramnegative cocco-bacillus producing minute colonies about $0.5 \mathrm{~mm}$. diam. Anaerobic cultures yielded in addition a scanty growth of Clostridium welchii. The cocco-bacillus showed no growth on unenriched nutrient media and did not, in early subcultures, show satellitism around colonies of Staphylococcus aureus; moreover growth was not improved by substituting chocolate agar for blood agar. It was decided that this organism might be an unusual member of the genus Haemophilus. It was given the laboratory reference number s 3105 .

\section{Morphology, colonial appearance and growth in liquid media}

The organism s 3105 was a small Gram-negative cocco-bacillus with occasional filamentous forms, resembling some strains of Haemophilus influenzae. It was noncapsulated, non-sporing, and non-motile after growth at $25^{\circ}$ and $37^{\circ}$. Colonies on horse blood agar in $24 \mathrm{hr}$ were small and pin-point, $0.5 \mathrm{~mm}$. or less in diam. In $48 \mathrm{hr}$ they were slightly larger, round, smooth, convex, greyish, butyrous in consistency and easily emulsifiable. In 3-4 days the colonies had enlarged to a diameter of about $\mathrm{I} \cdot \mathrm{\textrm {mm }}$. but no increase in size occurred on further incubation. There was no haemolysis or other alteration of the horse blood. In suitable liquid media growth occurred as a moderate uniform turbidity with slight deposit and no pellicle or surface ring.

\section{Optimum gas-phase conditions, temperature and $\mathrm{pH}$ value}

The organism s 3105 was aerobic and facultatively anaerobic. Growth under anaerobic conditions was almost as good as that in air; carbon dioxide had no appreciable effect. The optimum temperature was $37^{\circ}$; growth at $30^{\circ}$ was poor and at $25^{\circ}$ very poor or absent. The optimum $\mathrm{pH}$ value was $7-7 \cdot 5$; no growth occurred below $\mathrm{pH} 6$ or above $\mathrm{pH} 9$.

\section{Nutritional requirements}

Large inocula gave erratic results; growth occurred sometimes on simple media. For consistent and reproducible results it was found essential to use small inocula. Under these conditions no growth was apparent in Koser citrate medium, peptone water or Lemco nutrient broth, or on peptone water agar or Lemco nutrient agar when incubated aerobically. Slight growth occurred on anaerobic Lemco nutrient agar plates. The organism grew well aerobically on Lemco nutrient agar enriched with $10 \%(\mathrm{v} / \mathrm{v})$ horse blood, and almost equally well on the same medium base enriched with $10 \%$ (v/v) horse serum; heating the blood (chocolate agar) did not enhance growth. Good 
growth was obtained on peptone water agar containing both X- and V-factors or $\mathrm{X}$-factor alone, but no growth occurred when this basal medium was enriched with $\mathrm{V}$-factor only. The adequacy for growth of peptone water agar enriched with X-factor was tested by subculture on this medium. Eight serial transfers of the organism were made with ease from small inocula, the experiment then being discontinued.

Similar findings were obtained with liquid media. There was minimal or no growth in simple media but good growth in peptone water and in Lemco broth enriched with horse serum or with X-factor. No growth occurred in these media containing V-factor only, nor in Koser citrate medium enriched with $\mathrm{X}$-factor. The growth-promoting effect of serum was probably due to contamination with $\mathrm{X}$-factor; the batch of serum used gave a strongly positive benzidine reaction.

After repeated subculture on enriched medium the strict requirement for X-factor might be lost and slight growth occur even on peptone water media. This, however, was never as good as in the presence of X-factor.

When freshly isolated the organism did not show satellitism near staphylococci on any medium. After repeated laboratory subculture slight growth occurred in the neighbourhood of staphylococcal colonies on peptone water agar with or without V-factor; this satellite growth could be propagated through several subcultures. On $\mathrm{X}$-factor containing media there was never any evidence of satellitism. Further experiments were done using nicotinamide adenine dinucleotide (NAD) instead of yeast extract to supply V-factor; the final concentration of this substance in the medium was $10 \mu \mathrm{g} . / \mathrm{ml}$. The present isolate was tested in parallel with a strain of Haemophilus influenzae freshly isolated in this laboratory and with a strain of $H$. aphrophilus obtained from the National Collection of Type Cultures, London (NCTC 5886). The results are shown in Table $\mathrm{I}$.

Table I. Effect of nicotinamide adenine di-nucleotide $(N A D)$ on growth of strain $S 3105$ and of Haemophilus influenzae

\begin{tabular}{|c|c|c|c|c|c|}
\hline Strains & $\begin{array}{c}\text { Peptone } \\
\text { water agar }\end{array}$ & $\begin{array}{c}\text { Peptone water } \\
\text { agar }+ \\
\text { X-factor }\end{array}$ & $\begin{array}{l}\text { Peptone water } \\
\text { agar }+ \\
\text { NAD } \\
\text { (Io } \mu \mathrm{g} . / \mathrm{ml} .)\end{array}$ & $\begin{array}{l}\text { Peptone water } \\
\text { agar }+ \\
\text { X-factor }+ \\
\text { NAD }\end{array}$ & $\begin{array}{l}\text { Blood } \\
\text { agar }\end{array}$ \\
\hline $\begin{array}{l}\text { s } 3105 \\
\text { Haemophilus influenzae } \\
\text { H. aphrophilus } \\
\text { NCTC } 5886\end{array}$ & $\begin{array}{l}- \\
- \\
-\end{array}$ & $\begin{array}{l}++ \\
- \\
++\end{array}$ & $\begin{array}{l}- \\
- \\
-\end{array}$ & $\begin{array}{c}++ \\
+++ \\
++\end{array}$ & $\begin{array}{l}++ \\
++ \\
+++\end{array}$ \\
\hline
\end{tabular}

No growth of the present isolate occurred in the absence of X-factor, indicating that the staphylococcal factor causing satellitism was not NAD and was probably related to haematin. Heating experiments showed that the staphylococcal factor was destroyed by autoclaving at $12 \mathrm{I}^{\circ}$ for $\mathrm{I} 5 \mathrm{~min}$. but not by heating at $70-80^{\circ}$ for $10 \mathrm{~min}$. It is perhaps worth noting here a possible fallacy in the common practice of relying on satellitism for the demonstration of $\mathrm{V}$-factor requirement.

\section{Action on carbohydrates}

Acid without gas was produced in 2-3 days from xylose, glucose, galactose, lactose, maltose and salicin, in 5 days from rhamnose, sucrose, raffinose and inulin, and in 
I5 days from arabinose. Mannitol, dulcitol, adonitol, sorbitol and inositol were not attacked. Glucose was fermented, not oxidized. Starch plates showed a small zone of hydrolysis.

\section{Other biochemical reactions}

Tests for oxidase, urease, catalase, indole, serum liquefaction and gelatin liquefaction were all negative. Nitrates were not reduced. Litmus milk enriched with $\mathrm{X}$-factor showed acid and clot production in 3-5 days. There was no decarboxylation of lysine, deamination of phenylalanine or utilization of sodium malonate. There was no opacity on egg-yolk plates, no hydrolysis of casein and no fibrinolysin production.

\section{Haemolysis and haemagglutination}

There was no haemolysis in plates containing horse, human, rabbit, sheep or chicken red blood cells. There was no agglutination of human group $\mathrm{O}$, rabbit or chicken red cells at room temperature or at $4^{\circ}$. No attempt was made to demonstrate a soluble haemolysin.

\section{Tolerance to sodium chloride and inhibitory agents}

Good growth occurred in the presence of $0.5 \%$ and $\mathrm{I} \cdot 5 \%$ sodium chloride but partial inhibition was caused by $2.5 \%$ and complete inhibition by $3.5 \%$. There was no growth on plates containing $1 / 15,000$ potassium tellurite, $1 / 2,500$ sodium azide or I/ I 25,000 crystal violet, but the organism grew moderately well in the presence of I/5000 sodium azide and $1 / 250,000$ and $I / 500,000$ crystal violet. By the disc method, the organism was sensitive to novobiocin, chloramphenicol, ampicillin, tetracycline and nitrofurazone, and resistant to penicillin, streptomycin, neomycin and erythromycin. In tube dilution tests the organism was resistant to 25 units penicillin $/ \mathrm{ml}$. but sensitive to 50 units $/ \mathrm{ml}$; it was resistant to at least $100 \mu \mathrm{g}$. neomycin $/ \mathrm{ml}$.

\section{Viability, and resistance to heat}

The organism was very sensitive to heating under the conditions of the test. Death occurred in seconds at $100^{\circ}$ and in less than $5 \mathrm{~min}$. at $56^{\circ}$. Viability tests showed survival for 2 weeks (when the experiment was discontinued) at room temperature and at $37^{\circ}$ and for at least 4 weeks at $4^{\circ}$.

\section{Pathogenicity for laboratory animals}

A suspension in peptone water from a $48 \mathrm{hr}$ blood agar plate diluted to the opacity of a No. I Brown's opacity tube, was injected intramuscularly into a guinea-pig $(0.5 \mathrm{ml}$.) and intraperitoneally into a mouse $(0.2 \mathrm{ml}$.). No local lesions developed and the animals remained well. After 7 days both animals were killed. Post-mortem examination showed no lesions.

\section{Possible natural habitat}

An attempt was made to isolate further strains of this organism from laboratory specimens. The specimens were plated on a selective medium based on the resistance of the organism to various inhibitory agents. The medium used was Lemco nutrient agar containing horse blood $10 \%(\mathrm{v} / \mathrm{v})$, crystal violet $\mathrm{I} / 500,000$ final concentration, penicillin I unit $/ \mathrm{ml}$. and neomycin Io $\mu \mathrm{g} . / \mathrm{ml}$. This medium proved very satisfactory and yielded pure cultures even from faeces. It may, however, have suppressed the 
growth of strains sensitive to one or other of the selective agents used, if such strains exist. In all, 364 specimens were examined including I30 nose and throat swabs, I Io sputa, Ioo faeces, I4 vaginal swabs and Io miscellaneous specimens. The only positive finding was the isolation from $2 / 100$ faeces specimens of a heavy pure growth of an organism resembling the original isolate. Both positives were from normal children aged 6 months. The isolations were made at different times and there was no known contact between the children or between them and the original patient. The two new strains were given the laboratory reference numbers v 196 and v 23I. Detailed examination of these isolates gave virtually identical results to those obtained with the original strain s 3105 , except that both fermented arabinose more quickly and strain V I96 did not ferment inulin.

\section{Antigenic structure}

Antisera were prepared in rabbits against the original isolate s 3105 and against strain V 23I. Each antiserum agglutinated to high titre suspensions of the homologous organism. Formolized and heated suspensions gave similar titres but formolized suspensions were agglutinated in $3-4 \mathrm{hr}$ whereas heated suspensions required overnight incubation at $52^{\circ}$. Antiserum s 3105 gave no agglutination with antigens of strains V I 96 and V 23I. Similarly, antiserum V 23I did not agglutinate strains V 196 and s 3I05. Thus no antigenic relationship was demonstrated between the three cultures.

\section{DISCUSSION}

$\mathrm{X}$-factor is associated with the formation of various cytochrome haematins and catalase. The latter is a relatively heat-stable enzyme which apparently can replace $\mathrm{X}$-factor with some strains of Haemophilus influenzae (Brumfit, 1959). White \& Granick (1963) showed that the haematin biosynthetic pathway of haemin-independent Haemophilus is similar to that used in animals, plants and other micro-organisms, and proceeds through the steps

$\delta$-aminolaevulic acid $\rightarrow$ porphobilinogen $\rightarrow$ uroporphyrinogen III $\rightarrow$

coproporphyrinogen $\rightarrow$ protoporphyrinogen $\rightarrow$ protoporphyrin IX $\rightarrow$ haematin.

They confirmed Brumfitt's (1959) finding that protoporphyrin IX, but not earlier precursors, could substitute for haematin in the case of $H$. influenzae, but found that this was not so with the strain of $H$. aegyptius tested, which required fully formed haematin. Mannheim (1965) showed that the cell-free culture fluid of a strain of Achromobacter metalcaligenes supplied the X-factor requirements of $H$. influenzae but not of $H$. aegyptius. This substance was sensitive to light, was relatively heat-labile, and was thought to be a porphyrinogen, a haematin-precursor. Mannheim (1966) showed that a similar diffusible substance was produced by a wide variety of organisms including a strain of Staphylococcus epidermidis ( $S$. albus). Satellitism of staphylococcal colonies by the present isolate S 3105 could be due to the production by the staphylococci of such a substance; the original strict requirement for haematin itself may be lost on subculture and growth may become possible in the presence of haematin precursors.

The two X-factor requiring Haemophilus species known to cause infection in man are $H$. ducreyi and $H$. aphrophilus. Lwoff \& Pirosky (1937) examined 2I laboratory strains of $H$. ducreyi which over a period of years had become accustomed to grow on ordinary blood agar media, although none of these grew in simple peptone water. 
They found that haematin (X-factor) was an adequate substitute for blood, but Vfactor was ineffective. Pittman's (1957) classification of this organism as an X-factor requiring species is based on Lwoff's findings. Beeson (1946) and Ajella, Deacon, Paul \& Walls (1956) were unable to obtain growth in the presence of X-and V-factors alone or in combination, and most workers agree that primary isolation is difficult even on enriched media, special media being required. It seems evident that the growth requirements of recently isolated strains of $H$. ducrey $i$ are not satisfied by enrichment with X-factor alone. Haemophilus aphrophilus was isolated by Khairat (1940) from a case of endocarditis, this organism had the characteristic property of failing to grow in air on primary isolation, the presence of $\mathrm{CO}_{2}$, preferably in concentration of $5 \%(\mathrm{v} / \mathrm{v})$, being necessary; peptone water enriched with $\mathrm{X}$-factor provided all the essentials for growth. On repeated subculture, however, both $\mathrm{CO}_{2}$ and $\mathrm{X}$-factor might become unnecessary, growth occurring in air on peptone water media. King \& Tatum (I962) found that even recently isolated strains of $H$. aphrophilus grew on unenriched nutrient media in air without added $\mathrm{CO}_{2}$, and had no requirement for X- and V-factors. Biochemically $H$. aphrophilus does not ferment arabinose, xylose, rhamnose or salicin but reduces nitrates to nitrites (Khairat, 1940; King \& Tatum, 1962). Haemophilus ducreyi ferments no sugars (Reymann, 1949; Ajella et al. 1956). Both organisms therefore differ in growth requirements and in biochemical reactions from the present isolates.

Haemophilus haemoglobinophilus, $H$. ovis and $H$. influenzaemurium have been isolated from animals but not from man. H. haemoglobinophilus is found in the prepuce of normal dogs. Freshly isolated strains grow adequately on peptone water media enriched only with X-factor, but the organism differs from the present isolates in fermenting mannitol but not lactose, maltose or arabinose and in reducing nitrates to nitrites (Rivers, 1922). H. ovis was isolated by Mitchell (1926) from haemorrhagic bronchopneumonia of sheep. An autoclave-stable factor present in blood, presumably $\mathrm{X}$-factor, was necessary for primary isolation, but for optimal growth an autoclavelabile factor was also required. The species differs from the present strains in fermenting mannitol and sorbitol but not arabinose, rhamnose or salicin, in reducing nitrates to nitrites and in being highly virulent for the guinea-pig. $H$. influenzaemurium was first isolated by Kairies \& Schwartzer (1936) from mice with bronchopneumonia and also from the upper respiratory tract of normal mice. Its requirement of $\mathrm{X}$-factor was demonstrated by Ivanovics \& Ivanovics (1937). Information regarding biochemical reactions is scanty, but this organism differs from the present isolates in failing to produce acid and clot in litmus milk and in its pathogenicity for mice.

A further organism to be considered is the bacillus first isolated by Leopold (1953) and named Haemophilus vaginalis by Gardner \& Dukes (1955). The X-and V-factor requirements of this organism are not clear. Edmunds (1960) and Dukes \& Gardner (I96I) showed that X-factor was ineffective in a basal medium. Moreover, all authors are agreed that this is an exacting species and special media are recommended for isolation and subculture. Zinnemann \& Turner (1963) consider that $H$. vaginalis is in fact a Gram-positive bacillus and should be re-named Corynebacterium vaginale. It appears to bear no relationship to the present isolates.

Table 2 shows the growth requirements and Table 3 the biochemical reactions of the present isolates together with those of named species.

The three strains (s 105, V I96, v 23I) under study form a homogeneous bio- 


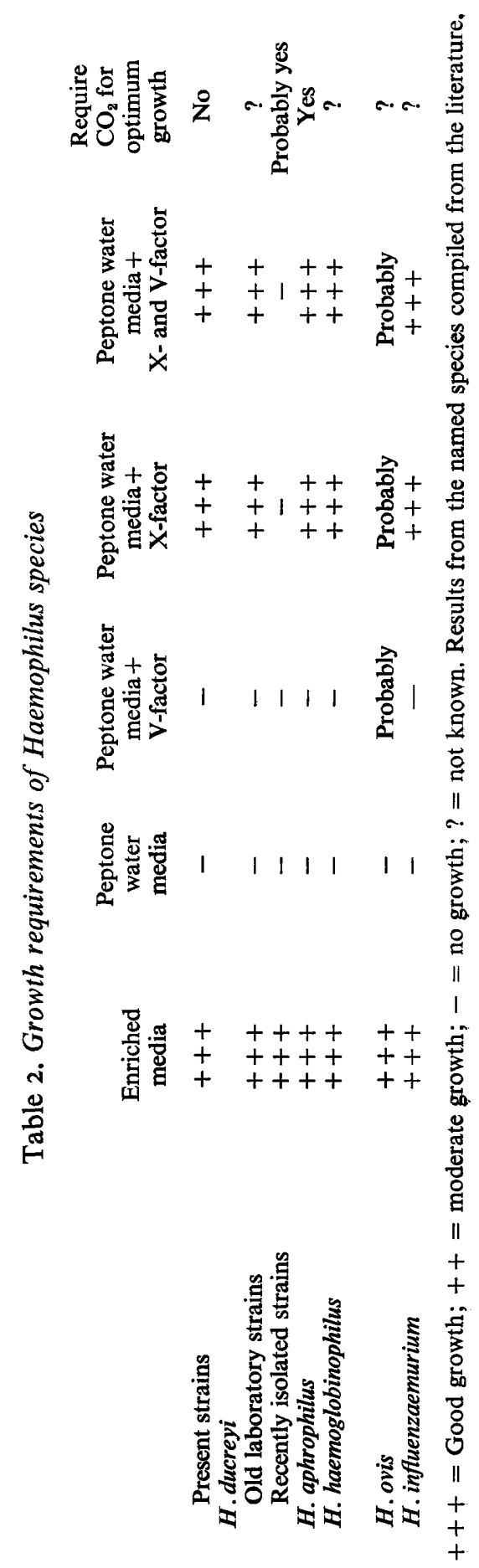


chemical and cultural group although antigenically they are heterogeneous. Their biochemical reactions distinguish them from all hitherto described $\mathrm{X}$-factor requiring Haemophilus species, although with $H$. influenzaemurium the distinction must be made solely on acid and clot production in litmus milk. This, however, was a very constant and characteristic feature of these strains which, moreover, showed no pathogenicity for mice. Their lack of requirement for $\mathrm{CO}_{2}$ further differentiates them from $H$. aphrophilus as even the aerobic strains of King \& Tatum showed enhanced growth under increased $\mathrm{CO}_{2}$ tension. Growth requirements alone are sufficient to distinguish them from $H$. ducreyi and $H$. vaginalis; biochemical reactions confirm this distinction. The guinea-pig pathogenicity of $H$. ovis is characteristic and the biochemistry of this organism and of $H$. haemoglobinophilus quite distinctive.

Table 3. Biochemical reactions of Haemophilus species

\begin{tabular}{|c|c|c|c|c|c|c|}
\hline & $\begin{array}{l}\text { Present } \\
\text { strains }\end{array}$ & $\begin{array}{c}H . \\
\text { ducreyi }\end{array}$ & $\begin{array}{c}H . \\
\text { aphro- } \\
\text { philus }\end{array}$ & $\begin{array}{c}H . \\
\text { haemo- } \\
\text { globino- } \\
\text { philus }\end{array}$ & $\begin{array}{l}\text { H. } \\
\text { ovis }\end{array}$ & $\begin{array}{c}H . \\
\text { influenzae } \\
\text { murium }\end{array}$ \\
\hline Arabinose & A & - & - & - & - & . \\
\hline Rhamnose & A & - & - & & - & . \\
\hline Xylose & A & - & - & A & A & \\
\hline Glucose & A & - & A & A & A & A \\
\hline Galactose & $\mathbf{A}$ & - & V & A & $\mathbf{A}$ & . \\
\hline Lactose & A & - & A & - & $\mathbf{A}$ & . \\
\hline Maltose & $\mathbf{A}$ & - & A & - & A & $\dot{A}$ \\
\hline Sucrose & A & - & A & A & A & A \\
\hline Raffinose & A & - & V & . & A & . \\
\hline Adonitol & - & - & - & . & . & . \\
\hline Dulcitol & - & - & - & - & & . \\
\hline Mannitol & - & - & - & A & A & - \\
\hline Sorbitol & - & - & - & . & $\mathbf{A}$ & . \\
\hline Inositol & - & - & - & . & - & . \\
\hline Salicin & A & - & - & . & - & . \\
\hline Starch & Hydrolysed & - & A & . & . & . \\
\hline Oxidase & - & - & - & . & . & \\
\hline Urease & - & . & Usually - & . & . & . \\
\hline Catalase & - & . & - & 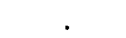 & . & . \\
\hline Nitrate reduction & - & - & + & + & + & . \\
\hline Indole & - & - & - & + & - & - \\
\hline Gelatin liquefaction & - & - & - & . & . & - \\
\hline $\begin{array}{l}\text { Coagulated serum } \\
\text { liquefaction }\end{array}$ & - & - & . & . & . & . \\
\hline Litmus milk & $\mathrm{AC}$ & . & Weak A & - & - & - \\
\hline
\end{tabular}

$\mathrm{A}=$ acid $\mathrm{AC}=$ acid and clot $++=$ positive reaction; $-=$ negative reaction; $\mathrm{V}=$ variable results. Reactions of the named species compiled from the literature.

On the available evidence the present isolates are most appropriately considered as a variety of $H$. influenzaemurium. Unfortunately the recorded findings on this species are incomplete and a strain was not available for comparison.

It does seem questionable whether any of the X-factor requiring Haemophilus species, with the exception of Ducrey's bacillus, merit specific status; they might perhaps be more suitably described as varieties of $H$. haemoglobinophilus.

Haemophilus has seldom been reported in the gut or gut contents, perhaps because of the difficulty of isolation. Rogers, Zinnemann \& Foster (1960) reported the finding 
of Haemophilus influenzae in perianal abscesses and in the lumen of appendices removed at operation. Bishop \& Allcock ( 1960 ) recorded the isolation of $H$. aphrophilus from the proximal loop of small intestine in a case of acute intestinal obstruction; its presence was thought to be due to ingestion and a causal role was not suggested. A small Gram-negative bacillus thought to be a Haemophilus species was isolated by Kok, Dybkaer \& Rostgaard (1964) from jejunal biopsies in a patient with Whipple's disease. Its pathogenic significance was not definitely determined.

The pathogenic role of the present original isolate, strain s 3105, remains doubtful. Obviously the lesion was exposed to faecal contamination as evidenced by the presence of Escherichia coli and Clostridium welchii. The Haemophilus species was, however, the predominant organism; indeed its presence would otherwise hardly have been detected. Unfortunately serum from the patient was not available for antibody titration. After treatment with tetracycline, scanty flora of normal faecal type was isolated and haemophilic bacilli were no longer found. The patient's faeces were not examined for Haemophilus as a suitable selective medium had not then been developed.

Strain s 3105 has been deposited with the National Collection of Type Cultures, Central Public Health Laboratory, Colindale, London, as NCTC I0555.

I am indebted to the National Collection of Type Cultures, London, for the culture of Haemophilus aphrophilus NCTC 5886.

\section{REFERENCES}

Ajella, G. W., Deacon, W. E., Paul, L. \& Walls, K. W. (1956). Nutritional studies of a virulent strain of Haemophilus ducreyi. J. Bact. 72, 802.

BEESON, P.B. (1946). Studies on chancroid. Iv. The Ducrey bacillus : growth requirements and inhibition by antibiotic agents. Proc. Soc. exp. Biol. Med. 6r, 8I.

Bishop, R. F. \& AllCOCK, E. A. (I960). Bacterial flora of the small gut in acute intestinal obstruction. Br. med. J. i, 766.

BoYD, W. C. (1947). Fundamentals of Immunology, 2nd ed., p. 402. New York: Interscience Publishers Ltd.

BRUMFITT, W. (1959). Some growth requirements of Haemophilus influenzae and Haemophilus pertussis. J. Path. Bact. 77, 95.

Christensen, W. B. (I946). Urea decomposition as a means of differentiating Proteus and paracolon cultures from each other and from Salmonella and Shigella types. J. Bact. 52, 461.

Christie, R. \& Wilson, H. (194I). A test of staphylococcal fibrinolysis. Aust. J. exp. Biol. med. Sci. I9, 329.

Cook, G. T. (1950). A plate test for nitrate reduction. J. clin. Path. 3, 359.

Duguid, J. P. (195I). The demonstration of bacterial capsules and slime. J. Path. Bact. 63, 673.

DUKES, C. D. \& GARDNER, H. L. (I96I). Identification of Haemophilus vaginalis. J. Bact. 8I, 277.

Edmunds, P. N. (1960). The growth requirements of Haemophilus vaginalis. J. Path. Bact. 80, 325.

GarDner, H. L. \& DuKes, C. D. (1955). Haemophilus vaginalis vaginitis. A newly defined specific infection previously classified 'non-specific vaginitis'. Am. J. Obstet. Gynaec. 69, 962.

Gillies, R. R. (1960). In Mackie and McCartney's Handbook of Bacteriology, Ioth ed. Ed. by R. Cruickshank, p. 609. Edinburgh and London: Livingstone.

Hugh, R. \& LeIfson, E. (I953). Taxonomic significance of fermentative v. oxidative metabolism of carbohydrates by various Gram-negative bacteria. J. Bact. 66, 24.

Ivanovics, G. \& Ivanovics, Ch. (1937). Beiträge zur Kenntnis des 'Bacterium influenzae-murium' (Kairies \& Schwartzer). Zentbl. Bakt. ParasitKde. (Abt. I. Orig.), 139, 184.

KaIrIES, A.\&SchwARTZER, K.(1936). Studien zu einer bakteriellen Influenza der Mäuse und Beschreibung eines 'Bacterium influenzae-murium'. Zentbl. Bakt. ParasitKde (Abt. r. Orig.), 137, 35 I.

Khairat, O. (1940). Endocarditis due to a new species of Haemophilus. J, Path. Bact. 50, 497. 
KING, E. O. \& TATUM, H. W. (1962). Actinobacillus actinomycetemcomitans and Haemophilus aphrophilus. J. infect. Dis. III, 85.

KoK, N., DybKaer, R. \& RostGaArd, J. (1964). Bacteria in Whipple's disease. Results of cultivation from repeated jejunal biopsies prior to, during, and after effective antibiotic treatment. Acta path. microbiol. scand. 60, $43 \mathrm{I}$.

Lwoff, A. \& PIRosky, J. (1937). Détermination du facteur de croissance pour Haemophilus ducreyi. C. r. Séanc. Soc. Biol. 124, I169.

LeOpold, S. (1953). A heretofore undescribed organism isolated from the genitourinary system. U.S. Armed Forces med. J. 4, 263.

MANNHEIM, W. (1965). Untersuchungen über einen bakteriellen Haemophilus-X-Faktor. I. Nachweis, Produktion und Stabilität des Faktors in komplexen Medien. Zentbl. Bakt. ParasitKde (Abt. I. Orig.), 198, 516.

MANNHEIM, W. (1966). Untersuchungen über einen bakteriellen Haemophilus-X-Faktor. II. Verbreitung des Wuchsfaktors bei heterotrophen Bakterien. Zentbl. Bakt. ParasitKde (Abt. I. Orig.), 200, 100.

Mitchell, C. A. (1926. Haemophilus ovis (nov.spec.) as the cause of a specific disease in sheep. J. Am. vet. med. Assoc. 68, 8.

PrtTman, M. (1957). In Bergey's Manual of Determinative Bacteriology, 7th ed. Ed. by R. S. Breed. E. G. D. Murray and N. R. Smith, p. 407. Baltimore: The Williams and Wilkins Co.

REYMANN, F. (1949). Investigation of the biochemical reactions of Haemophilus ducreyi. Acta path. microbiol. scand. 26, 345.

RrVERs, T. M. (1922). Bacillus haemoglobinophilus canis. J. Bact. 7, 579.

ROGERS, K. B., ZINNEMANN, K. \& FosteR, W. P. (1960). Isolation and identification of Haemophilus species from unusual lesions in children. J. clin. Path. r3, 519.

Shaw, C. \& Clarke, P. H. (1955). Biochemical classification of Proteus and Providence cultures. J. gen. Microbiol. $\mathbf{1 3}, \mathrm{I} 55$.

Stokes, E. J. (1960). Clinical Bacteriology, 2nd ed. p. 290. London: Arnold.

WATSON, K. C. \& BENNET, M. A. E. (1957). Gradient-type hydrogen ion concentration plates. J. lab. clin. Med. 5o, 639.

White, D. C. \& Granick, S. (1963). Hemin biosynthesis in Haemophilus. J. Bact. 85, 842.

Zinneman, K. \& TURner, G. C. (1963). Taxonomic position of Haemophilus vaginalis. J. Path. Bact. 85, 213. 